\title{
ReSEARChArticle
}

\section{Stdiues on relationship among yield components and selection criteria for yield improvement in sorghum [Sorghum bicolor (L.) Moench]}

\author{
SUSHIL KUMAR
}

\section{SUMMARY}

Association and path analysis was attempted for six traits viz., days to 50 per cent flowering, plant height, panicle length, days to maturity, test weight and grain yield per plant. Thirty sorghum hybrids their respective parents and three checks were studied. Grain yield had expressed highly significant and positive correlation with plant height, panicle length, days to maturity and test weight at both genotypic and phenotypic levels, the characters that had positive direct effects on grain yield at both phenotypic and genotypic levels were test weight $(0.543,0.557)$, panicle length $(0.352,0.354)$, days to $50 \%$ flowering $(0.169,0.206)$ and days to maturity $(0.113,0.084)$. Plant height $(-0.108,-0.082)$ had direct effect in negative direction at both phenotypic level and genotypic level. The inter-relationship among these characters might be used in the breeding programme to exploit the yield potential and to develop high yielding improved varieties with ease and target oriented research.

Key Words : Hybrids, Correlation, Path co-efficient, Sorghum

How to cite this article : Kumar, Sushil (2017). Stdiues on relationship among yield components and selection criteria for yield improvement in sorghum [Sorghum bicolor (L.) Moench] . Internat. J. Plant Sci., 12 (2): 156-159, DOI: 10.15740/HAS/ IJPS/12.2/156-159.

Article chronicle : Received : 21.03.2017; Revised : 03.05.2017; Accepted : 21.05.2017

\section{AUTHOR FOR CORRESPONDENCE}

SUSHIL KUMAR, Department of Genetics and Plant Breeding, Sardar Vallabhbhai Patel University of Agriculture and Technology, MEERUT, (U.P.) INDIA

Email: sushil_svbp@rediffmail.com 